\title{
Multilinguales
}

1 | 2013

Pratiques littéraires, linguistiques, pédagogiques,

didactiques et médiations culturelles contemporaines

\section{Using multimedia labs in enhancing EFL Students' research methods}

L'enseignement multimédia en méthodologie de la recherche universitaire

\section{Nadia Idri}

\section{(2) OpenEdition}

\section{Journals}

Electronic version

URL: https://journals.openedition.org/multilinguales/3108

DOI: $10.4000 /$ multilinguales.3108

ISSN: 2335-1853

\section{Publisher}

Université Abderrahmane Mira - Bejaia

Printed version

Date of publication: 1 June 2013

Number of pages: 80-93

ISSN: 2335-1535

\section{Electronic reference}

Nadia Idri, "Using multimedia labs in enhancing EFL Students' research methods", Multilinguales [Online], 1 | 2013, Online since 01 June 2013, connection on 02 July 2021. URL: http:// journals.openedition.org/multilinguales/3108; DOI: https://doi.org/10.4000/multilinguales.3108

This text was automatically generated on 2 July 2021.

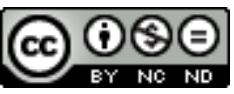

Multilinguales est mise à disposition selon les termes de la Licence Creative Commons Attribution Pas d'Utilisation Commerciale - Pas de Modification 4.0 International 


\title{
Using multimedia labs in enhancing EFL Students' research methods
}

\author{
L'enseignement multimédia en méthodologie de la recherche universitaire
}

\author{
Nadia Idri
}

1 Technology education has become a critical issue of discussion in all learning settings. Using technology is no more linked to technical sciences or information science although it has been used in teaching for centuries (Cennamo, Ross \& Ertmer, 2010). This led many researchers, educators and decision-makers to inquire about implementing technology to foster learning and teaching in a variety of ways. Again, it is becoming more than a must in all educational fields where Foreign Language Learning (FLL) is of interest for educators, researchers and administrators. Within the LMD reform, technology is introduced and reinforced through Information and Communication Technology (ICT) to encourage information literacy. Such reform puts focus on Research Methodology as a subject that accompanies the English as a Foreign Language (EFL) student from the first year to the master degree in order to develop in learners the necessary skills and competences to conduct research. As concerns reform, it is supposed to bring changes in terms of the student's development (Idri, 2012). In this regard, Idri (2012) states that the LMD reform suggests new teaching subjects, defends both technology use and updated teaching methods use. For her, there is a big gap between administrative official texts and their application. This shows that technology is still not introduced in our classes. Hence, this paper claims that there is an urgent need to introduce technology while teaching research methodology and multimedia labs are an example for that. Our university possesses six multimedia laboratories under the name of Sanako lab $250 \mathrm{v}$. 2.0. This technology remains unfortunately not well exploited and there is the need to employ our available technology tools to teach this subject more effectively. 


\section{The role of technology in language teaching}

2 It is common knowledge that since the last three decades, technology has made learning and teaching more effective and more interesting. Cennamo et al. (2010) claim, in this concern, that technology offers a powerful resource for engaging students in authentic experiences, typically increasing both their motivation and their learning. This is more likely to lead students to be much more engaged with technology. Fang Xu (2003) argues that besides facilitating greater interaction, technologies, when appropriately integrated, support experiential learning and practice in a variety of modes, provide effective feedback to learners, enable pair and group work, promote exploratory and global learning, enhance student achievement and provide access to authentic language learning materials (Warschauer and Healey, 1998). As concerns educational reforms in many countries, they have common objectives and prospects for technology dispersal in education to contribute to equity and decentralization, pedagogical modernization, and teacher professionalization (Potashnik, 1996). These have to do with what the LMD reform aims at through the variety of new contents elaborated in teaching foreign languages in order to fit international needs.

3 In this paper, we share the view that technology has positive effects on learning and teaching, on the learner and on the teacher since it can improve education (Selwyn, 2011). Several studies (E.G. Becker, 1982; Wenglinsky, 1998) related to specific applications of technology evidence that, when used appropriately, technology can lead to improvements in student's performance, motivation and empowerment by putting focus on complex problem solving, project-oriented approaches to subject matter and apprenticeships composed of authentic tasks, sustained and challenging work (cited in Fang $\mathrm{Xu}, 2003: 13)$. Further, professional educators urge schools to optimize the learning and teaching environments where students can be freed from text-based curricula and teachers will be able to present their subjects in greater depth and sophistication (Ibid). This supports our position to teach research methodology using practice instead of being framed in a handout-based teaching. Indeed, we are in a need for such a basic change in the LMD system before considering it reform (Idri, 2012). In other words, our project defends the principle that teaching research methodology needs to be freed from theory and handouts. We assume that technology is more likely to facilitate the development of the needed skills in research if employed appropriately and regularly.

4 Technology can enhance and extend student learning in several ways and it can make complex processes clearer through the use of visuals and multiple examples found in online simulations or animations, images or photos from websites or CDs, or graphics or data tables. It is evident that our labs do offer this opportunity to use such different materials. Further, technology can help economize time and effort by allowing students to create and manipulate texts quickly and easily, and hence exploit the literature more efficiently. For the implementation of multimedia in teaching foreign languages, Vu Thi Phuong Thao (2000) can serve as an example. In his university, the Hanoi University of Foreign Studies (HUFS), the pioneer to explore the benefits of multimedia tools to assist language skills teaching; Vu Thi suggests including a network of computers and related software, cassette players, and slide projectors linked together to teach foreign languages. In our case, such tools are suggested in order to develop study skills and research methodology skills in particular in our students. 
5 Nevertheless, using multimedia is not always easy especially when dealing with largesize classes and students with little knowledge about technology use in FLL, a case we believe characterizes our students. $\mathrm{Vu}$ Thi (2000), for instance noted that the contribution of multimedia in supporting language learning at university is not obvious. The author mentioned a number of limitations and restrictions of learning styles, teaching approaches, and computer skills in Vietnam (Ibid). He ended his work with a number of recommendations for teachers' adjustment, more active participation of students and adequate computer skills since there is a problem of unfamiliarity with technology and multimedia (Ibid).

6 It is for this reason that we intend to relate technology to teaching research methodology. Here, concepts like computer literacy, information literacy and electronic literacy need to be known (c.f. Appendix 2). These are skills both teachers and learners need to acquire within the reform before ever thinking to use technology in teaching research methodology. Again, such a reform needs its means, such a reform needs technology, and it needs new methods of teaching its new implemented subjects. To reach this sought modernization, we need to think of its needed prerequisites of which technology is part. Here, we question whether Idri (2009) has been right when writing "The innovation that the Algerian universities are going to apply permits a real refoundation of the programmes which have been somehow inadequate to the development of the world and science as well » (Idri, 2009).

\section{Statement of the problem}

7 Despite the impending pledge that information technology can impact upon educational systems, studies on the field of ICT reported a number of detailed barriers to a successful and effective implementation of higher education reform with technology. Such obstacles were mainly linked to issues of school politics (Bryk, 1998), curriculum and assessment (Herman, 1994; Newman, 1994), and pedagogical approaches (Becker, 1993), among others including lack of staff development and technical support (Fang Xu, 2003). Among the media which can be employed in our FLL classes, we choose to consider multimedia labs. These can be useful to create virtual classrooms inside the real existing classroom. Using multimedia in our FFL classrooms is more likely to help both learners and teachers enhance their competences in a variety of ways. We can think of their application in teaching all subjects and skills.

8 Always under the heading of multimedia labs, these tools have been introduced as a means of teaching foreign languages in Algeria. In Béjaia, Abderrahmane Mira University has made this technology available since 2005 and two training sessions were organized to help teachers use this newly introduced technology in an efficient way. However, few teachers from the Department of English took part in the training sessions. In addition, this said Department is made up of a majority of part-time and associate teachers. This problem makes of these teachers unstable. That is to say, they are not permanently teaching in that Department and hence, the new teachers find themselves facing a virtual classroom for the first time. Another possible problem in the use of these labs is that they have been used to teach mere listening and phonetics, although the technology itself can be deployed with all subjects. We are also aware of the difficulty of using these labs since not all teachers and learners manipulate computers, and are not accustomed to social networks (a terminology often present in 
virtual classrooms). This is more likely to make their practical use complicated. In this, Osin (1998) shares the belief that computers enable teachers not only to get information from others but also present information, and adapt it to the students' needs, preferences or requests, and this is more likely to facilitate interaction through the means of technology.

It is for this main reason that our intention has been drawn to choose this topic in teaching one subject. A subject that is specifically introduced by the LMD system and has as an objective assuring highly qualified researchers. This subject is research methodology which can be taught under the form of group sessions. Within the group sessions, we can think of adding practical sessions in the multimedia labs. Hence, the problem we raise here is that research methodology is taught in a theoretical way and students even at advanced levels feel unable to approach a research task. We assume that learners do not practise what they learn in research methodology. Hence, our aim is to suggest using multimedia labs to organise practical, regular sessions to put theory of research methodology into practice (c.f. Figure 1).

Many questions are related to this issue :

1. Are Multimedia labs useful and effective in teaching all language skills; that are all required in research, and to which extent?

2. Do teachers and learners manipulate the laboratories' programmes?

3. Are learners accustomed to social networks and virtual classrooms? Is this technology used in our classrooms and to which extent?

4. In what way does this technology help learners practise research methods in such a virtual classroom?

5. Can we say that multimedia labs facilitate the classroom management; organization and guidance to help learners and teachers conduct research collaboratively?

6. Does this virtual classroom help learners develop their study skills (note-taking, reading, speaking, listening, writing, data collection, etc.)? 
Figure 1 : Multimedia Labs and Research Methodology Teaching

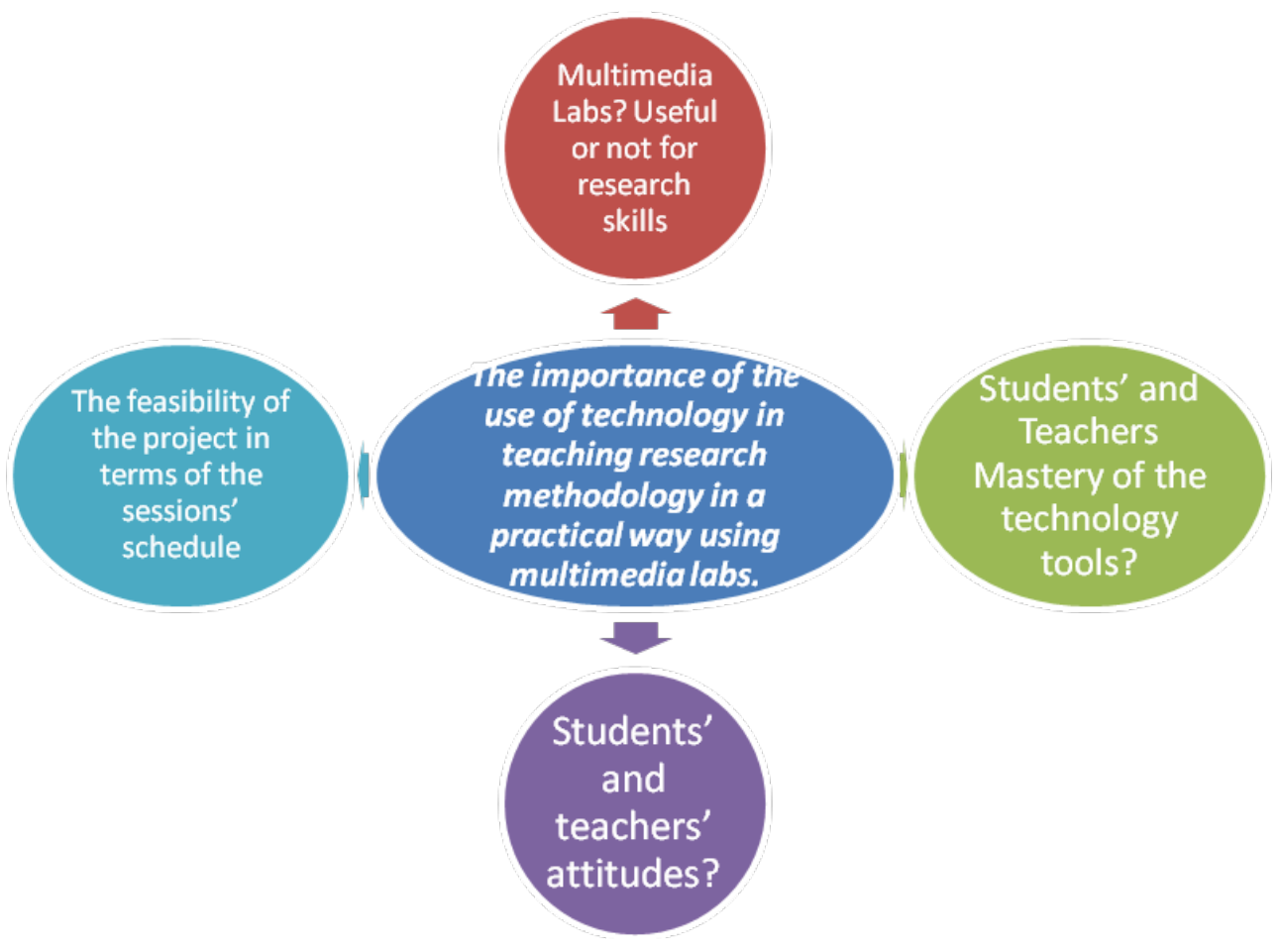

\section{Design and results}

11 To collect data, we worked with 15 volunteer first year students of English taking the course of research methodology. The researcher prepared the observation instrument and the tasks the part-time teacher should use in the practice stage of the lesson. Using the observation scheme prepared by the researcher, the teacher reported the observations in her two-sessions scheduled in the labs.

12 The Introduction of the SANAKO Lab 250 v. 2.0: SANAKO Lab 250 v. 2.0 is a pure software solution for transforming information technology classrooms (classrooms already equipped with networked computers) into interactive, audio-infused multimedia environments that can be used for teaching and learning a wide variety of subjects and skills ${ }^{1}$.

13 Sample: We have observed a number of 15 students who volunteered to attend the two multimedia sessions we arranged to test the learners' readiness for using multimedia and the practicability of the project we would like to suggest. These students were first year LMD students from different groups. A part-time teacher who has some mastery of the lab was in charge of the sessions.

Non-participant Observation: We used an observation scheme (designed by the researcher) to observe the teacher's role when using the labs, the teacher's mastery of the technology tool, the learners' reactions and involvement, classroom management via multimedia. This was through two multimedia sessions where we took the case of using the labs in searching online resources and sharing information about the course content. The lesson was about Dictionary Use, Using the Library and Online Search Engines ; introduced for the first time this year (2011/2012). 


\section{Results : technology and research methodology teaching}

Results from the two sessions showed that the teacher emphasized more on the technology than the content itself. This can be attributed to the wide number of enquiries requested from the students when meeting difficulties to follow the teacher's instructions. It is evident that such difficulties are to be met by students who experience such labs for the first time. During the first session, the teacher, instead of using the lab's functions to launch an online search about a selected topic by the students, was helping students identify the necessary buttons and find them like : the microphone, the bookmark buttons, how to play back audio and video files, etc. This prevented the teacher from respecting her lesson plan stages; she opted for the automonitor mode to control those students who could not follow the lab's use. At this stage, the teacher demonstrated how we can use such media in making an online search (through the intranet). She transferred the question: "Can anyone suggest a research topic to make an online search ?" For this, she has used the track transfer option.

Students were still reticent to participate. The assistant teacher here tried to demonstrate the use of multimedia labs by playing a compact disc, share its content, and send a collective email. The researcher and the responsible of the subject at the same time analysed the situation and prepared the content of the second session for the assistant teacher. The plan was to help learners use the lecture's content online. The teacher recommended the creation of a virtual classroom where information is to be shared. The students were required to write their email addresses (15 in number) and one student said that she has no email address. The instructor asked her to create an email account and join the online group. The creation of a google group outside the multimedia lab was meant to demonstrate how can students use the labs inside the classroom and expand its usage outside the classroom with the help of the instructor. It can be useful to develop team work in the learners, to share ideas and documents within the sessions and outside. On Tuesday, April, $24^{\text {th }}, 2012$, the researcher created the group: Research Method Space. Its link is: [http://groups.google.com/group/ research-methodspace]

The lecturer sent invitations to 15 students and 3 assistant teachers but students were requested to join the group outside the session when they open their emails because the labs do not have an internet connection (one of the problems we faced). Only three joined the group. The text she sent was:

"Dear Students:

I am glad to create this virtual space and online group sessions with you. You will receive feedback and content from my part and answer your questions. Do not hesitate to use this space. Best regards and be active. Ms Ahouari-Idri, N".

The second step was to upload and share documents related to Research Methodology via google docs outside the labs: [https://docs.google.com/\#home]

A wide range of document was uploaded and this took a long time, but no one downloaded.

The objective of using multimedia labs and creating the google group for out of lab use was :

Study Skills in Virtual Classrooms

Sharing discussions online 
Sharing documents, blogs, emails, in the virtual class created in the lab and expand this outside the lab via the "Research Methods Space Group"

Practice note-taking, use of electronic resources like online searches and search engines, download and upload documents, join together other social media relative to research methodology, etc.

Introduction to Research Methodology

Bibliographic research

Referencing

Reviewing

Tutoring and supervision

Introducing the Annual Content of Research Methodology and the Sanako Labs 250 v. 2.0 


\begin{tabular}{|c|c|c|}
\hline $\begin{array}{l}\text { - Tips on Studying a } \\
\text { Foreign Language } \\
\text { - Note-taking Tips } \\
\text { - Note-taking } \\
\text { Symbols } \\
\text { and Abbreviations } \\
\text { - Listen for Signal } \\
\text { Words } \\
\text { - Dictionary Use, } \\
\text { Using } \\
\text { the Library and } \\
\text { Online } \\
\text { Search Engines } \\
\text { - Listening } \\
\text { - Reading } \\
\text { - Writing } \\
\text { - Speaking } \\
\text { - Virtual Classrooms } \\
\text { (chatting, social } \\
\text { networks, video- } \\
\text { conferencing, etc.) }\end{array}$ & $\begin{array}{l}\text { - Bibliographic research } \\
\text { through online libraries } \\
\text { - The scientific spirit } \\
\text { - Characteristics of science } \\
\text { Research } \\
\text { - Methodology } \\
\text { - Research methodology } \\
\text { - Research Steps }\end{array}$ & $\begin{array}{l}\text { audio broadcast (audio source, cd, } \\
\text { microphone } \\
\text { talk, etc) } \\
\text { automonitor (monitor students' } \\
\text { computers) } \\
\text { bookmark (stops to turn to the file) } \\
\text { classmanager (create a class layout) } \\
\text { digital recorder (audio/video) } \\
\text { digitize (convert to digital format) } \\
\text { mediashare (broadcast through a } \\
\text { server) } \\
\text { mediaviewer (view shared media) } \\
\text { monitor (viewing and listening to } \\
\text { student activity } \\
\text { by individual or by group) } \\
\text { multimedia panel (monitoring a } \\
\text { student or several, } \\
\text { communicating with the students, } \\
\text { creating group } \\
\text { discussion sessions, and broadcasting } \\
\text { audio and } \\
\text { video) } \\
\text { self-study (students are able to work } \\
\text { alone) } \\
\text { student icons (student's status: remote, } \\
\text { model, etc) } \\
\text { teacher status } \\
\text { track transfer (select material, control } \\
\text { students' } \\
\text { attention) } \\
\text { videomanager (adding media files or } \\
\text { on-line } \\
\text { streams to the server) }\end{array}$ \\
\hline
\end{tabular}

From our observation, we can conclude that :

Students

Were interested in the labs but found difficulties in using the computers. We still have a problem at the level of computer and information literacy.

Have never used multimedia labs for research methodology practice as they merely used them for listening and phonetics as audio materials.

Were reticent to join the group and participate in an online discussion.

Teacher

Used the multimedia lab as a traditional lab although the technology can offer a variety of alternatives (a virtual classroom) 
Used the lab efficiently to make audio material available for students and help them record their answers. Yet, such labs cannot be used for the sake of online use like chatting, social networking, documents' sharing, online searches (intranet not internet).

\section{The Output : A Designed Questionnaire for Further Research}

Through our observation stage, we could develop a questionnaire we are actually testing. It is about: Multimedia and Research Methods Teaching. More details can be reached about the survey (c.f. [http://www.surveymonkey.com/s/Q92FCHG]. This piloting stage of the project led us to construct a plan for the project's applicability. For this, we suggest the following stages :

21 First of all, we need to get answers from our students through the developed questionnaire. This will help us identify the characteristics of our sample, their attitudes towards research methodology and towards the use of multimedia labs as well. Needs analysis will also be available to respond to the learners' needs while scheduling multimedia sessions.

Then, introductory sessions are needed to start up teaching these students research methodology. During this preparatory stage, we could observe the students informally, and then, formally, through the observation grill.

Our last step is organizing regular sessions in Béjaia University's labs where the participant observation will be made simultaneously with the experimental design. One group is the experimental to which the labs will be introduced. The second group will only be taught in its traditional methodology classes. Pre-tests and post-tests are to be made to both groups of students to compare the results. This will make the coming research stage.

\section{Final notes and implications}

We still need to plan for how to make use of technology tools in our universities.

Our learners' attitudes are positive about multimedia but feel reticent to use the labs.

Many teachers do not master multimedia fully especially when used for research purposes ; using technology is still challenging for our teachers.

We need to diagnose the teachers' readiness to use multimedia labs, test their attitudes and abilities before thinking of using them in teaching research methodology (linguistic, cultural and technical competences should be developed here to interpret the resources appropriately).

Our programmes and syllabi should fit technology use.

We need to prepare ready-made activities as part of the practice stage and the expansion stage of each lesson to guarantee a continuing usage of technology and, hence, be a facilitator to enhance the students' language and research skills (the google group or the servlist can be efficient here).

The computers' labs can help if equipped with appropriate software programmes that fit research methodology teaching (e.g. zotero, dropbox) 

(Six labs for the faculty and the Intensive Language Center) since we have large-size classes and too many groups (15 in 2001/2012 and 20 groups in 2012/2013). This makes it not possible to use the labs regularly. The next step of the present longitudinal study will be testing the hypothesis we generated in this pilot study which is «The implementation of practical sessions in the available multimedia labs as a new technology will help in developing research methods skills in first year LMD students of English at the University of Abderrahmane Mira, Bejaia ».

\section{BIBLIOGRAPHY}

BRYK, A. S. S., et al., Charting Chicago School Reform : Democratic Localism as a Lever for Change, Colorado : Westview Press, 1998.

CENNAMO. S. K, ROSS. D. J. \& ERTMER. P, Technology Integration for Meaningful Classroom Use: A Standards-Based Approach, Wadsworth, USA: Wadsworth Cengage Learning, 2010.

HERMAN, J. L, "Evaluating the Effects of Technology in School Reform' in Technology and School Reform : the Reality behind the Promise", in Means, B. (dir.), Technology and Education Reform : The Reality behind the Promise, San Francisco, CA : Jossey-Bass Inc, 1994.

IDRI, N., The LMD System Experience as a Struggle between Educational Development and Reform : An Analytical Study of the Endeavour of the Academic Year 2004/2005 in Béjaia University with Suggested Solutions". Published in http://www.eric.ed.gov. Ref : D504547, 2009.

IDRI, N., Education and Reform to Reach Autonomous Learners : Between Reality and Myth, Procedia-Social and Behavioral Sciences, $\mathrm{N}^{\circ}$ 69, 2012, p. $2174-2183$.

Newfields, T. \& Davis, R., “Multimedia in Language Teaching”. TESL-EJ, Vol 3, N 2, 1998. ISSN 1072-4303.

NEWMAN, D., “Computer Networks : Opportunities or Obstacles?" in Means, B. (dir.), Technology and education reform: The reality behind the promise, San Franciso, CA : Jossey-Bass Inc, 1994.

OSIN, L., “Computers in Education in Developing Countries: Why and how?", Washington, DC: World Bank Education and Technology Team, 1998.

POTASHNIK, M., Chile's Learning Network, Washington, DC: World Bank Education and Technology Team, 1996.

PAPERT, S., "Mindstorms : Children, Computers, and Powerful Ideas", New York : Basic Books, 1980.

SANAKO Lab 250 v. 2.0 Guide User, Tandberg Educational, SANAKO Corporation. Document date: 09.03.05. Production Code: 1871010-5068, 2005.

SELWYN, N., "Editorial: In Praise of Pessimism - the Need for Negatively in Educational Technology". British Journal of Educational Technology, 2011. 
WARSCHAUER, M. \& Healey D., “Computers and Language Learning: An overview”, Language

Teaching, 31, 1998, 57-71.

WARSCHAUER, M., "Dissecting the Digital Divide : Access and Stratification in the Age of Information", Cambridge, MA : MIT Press, 2003.

WENGLINSKY, H., "Does it Compute? The Relationship between Educational Technology and Student Achievement in Mathematics", Princeton, New Jersey : Educational Testing Service, 1998.

XU, F., “Toward Integrating Information Technology into Tertiary EFL Teacher Education "USChina", Foreign Language, ISSN 1539-8080, USA, 2003.

\section{NOTES}

1. SANAKO Lab 250 v. 2.0 Guide User (2005). Tandberg Educational. SANAKO Corporation. Document date : 09.03.05. Production Code : 1871010-5068

\section{ABSTRACTS}

This research is part of a long-term project which started in 2012 as a pilot study. It aims at using technology and suggesting a new method of teaching research methodology via the six multimedia labs our university has since 2005. We collected data through two non-participant observation sessions with 15 volunteer students. The outcome of this hypothesis-generating pilot study is a hypothesis and a questionnaire. Results revealed that students showed interest in the use of labs but still face problems in using the computers. For teachers, labs have never been used with their full advanced functions but are still used as an audio material (in listening and phonetics). Finally, large-size classes and the wide number of groups (15 in 2012) make it challenging for the project to be effective. The study is in progress based on the above results.

Cette recherche, entamée en 2012, est un projet pilote portant sur l'utilisation de la nouvelle technologie multimédia dans l'enseignement de la méthodologie de la recherche en langue anglaise. Nous avons procédé à une expérience non-participative avec 15 étudiants volontaires. Nous livrons ici les premiers résultats de l'enquête sur terrain, menée à l'université de Bejaia. Les premières analyses des données ont révélé que les étudiants ont montré un intérêt certain pour l'utilisation du laboratoire multimédia, mais qu'ils sont encore confrontés à des problèmes de manipulation. Quant aux enseignants, ils n'utilisent pas encore toutes les fonctions avancées de ce laboratoire réduit à un moyen audio (en phonétique). Même si l'observation est en cours, nous sommes parvenue à l'élaboration d'un questionnaire pour la prochaine phase de l'étude. 
INDEX

Mots-clés: laboratoire multimédia, anglais langue étrangère, méthodologie de la recherche, université de Bejaia, enseignement multimédia

Keywords: multimedia lab, English as a foreign language, research methodology, Bejaia university, multimedia teaching

\section{AUTHOR}

NADIA IDRI

A. Mira University - LAILEMM - Bejaia 